\title{
Peranan Pemberian Bokashi Sekam Padi Terhadap Pertumbuhan Dan Hasil Tanaman Tomat (Lycopersicum esculentum.Mill.)
}

\author{
Nining Sri Sukasih dan Veronika Jeli \\ Fakultas Pertanian Universitas Kapuas Sintang \\ Email: niningskasih@gmail.com
}

\begin{abstract}
Abstrak: Tanaman tomat merupakan tanaman sayuran banyak mengandung vitamin dan mineral yang sangat dibutuhkan oleh manusia untuk melengkapi keperluan gizi dalam hidupnya. Hasil tomat di Kalimantan Barat masih rendah, oleh karenanya perlu ditingkatkan. Salah satu kendala dalam meningkatkan pertumbuhan dan tomat di Kalimantan Barat adalah tanahnya yang didominasi oleh tanah PMK. Tanah PMK merupakan jenis tanah yang miskin bahan organik, oleh karenanya perlu penambahan pupuk organik, antara lain dengan pemberian bokashi sekam padi. Penelitian ini bertujuan untuk mengetahui pengaruh bokashi sekam padi terhadap pertumbuhan dan hasil tanaman toma. .Penelitian ini menggunakan metode eksperimen lapangan dengan pola rancangan acak kelompok (RAK), terdiri dari lima taraf yaitu $\mathrm{N}_{0}$ = Tanpa bokashi sekam padi (kontrol) $\mathrm{N}_{1}=$ Bokasi sekam padi $=1,5 \mathrm{~kg} / \mathrm{m}^{2} \mathrm{~N}_{2}=$ Bokashi sekam padi= $2 \mathrm{~kg} \mathrm{~m}{ }^{2} \mathrm{~N}_{3}=$ Bokashi sekam padi $=2,5 \mathrm{~kg} / \mathrm{m}^{2} \mathrm{~N}_{4}=$ Bokashi sekam padi $=3 \mathrm{~kg} / \mathrm{m}^{2}$. Parameter yang diamati adalah tinggi tanaman $(\mathrm{cm})$, jumlah buah, dan berat buah (gram).Data dianalisis dengan sidik ragam kemudian dilanjutkan dengan uji Beda Nyata Jujur (BNJ) pada selang kepercayaan 95\% dan 99\%.Hasil penelitian menunjukan bokashi sekam padi berpengaruh sangat nyata terhadap pertumbuhan dan hasil tanaman tomat. Pemberian $3 \mathrm{~kg} / \mathrm{m}^{2}$ bokashi sekam padi memberikan rerata pertumbuhan dan hasil tertinggi yang ditunjukan oleh peubah tinggi tomat $89,80 \mathrm{~cm}$, jumlah buah 7,85 , dengan rata-rata 31,75 buah pertanaman, berat buah 307,048 gram dengan rata-rata 1076,75 gram pertanaman.
\end{abstract}

Kata Kunci : Pertumbuhan, Hasil, Tomat, Bokashi Batang Pisang, Tanah Podsolik Merah kuning (PMK)

\section{PENDAHULUAN}

Tanaman tomat (Lycopersicum esculentum. Mill), merupakan tanaman sayuran banyak mengandung vitamin dan mineral yang sangat dibutuhkan oleh manusia untuk melengkapi keperluan gizi dalam hidupnya. Menurut Pracaya (2003:10), Nilai gizi yang terkandung dalam tiap $100 \mathrm{gr}$ buah tomat adalah air 0,3 gr, protein $1,0 \mathrm{gr}$, lemak $0,1 \mathrm{gr}$, Karbohidrat 4,0, serat 1,2 gr, Kalori $21,0 \mathrm{kal}$, pospor 30,0 mg, kapur 15,0 mg, besi 0,4 $\mathrm{mg}$, Vitamin A 1000,0 Iu, Vitamin B1 50,0 $\mu \mathrm{g}$, Vitamin B2 40,0 $\mu \mathrm{g}, \mathrm{C} 25,0 \mathrm{mg}$. Sebagai sumber vitamin, buah tomat sangat baik untuk mencegah dan mengobati berbagai macam penyakit, seperti sariawan karena kekurangan vitamin C, xeropthalmia pada mata karena kekurangan vitamin A, beri-beri, radang saraf, lemah otot-otot, dermatitis, bibir merah dan radang lidah karena kekurangan vitamin B. Sebagai sumber mineral, buah tomat bermanfaat untuk pembentukan tulang dan gigi (zat kapur dan fosfor) (Cahyono 1998:23).

Produksi tanaman tomat di Kabupaten Sintang masih rendah. Berdasarkan BPS PIPER No. 31 Volume 16 Oktober 2020
Kabupaten Sintang (2018:206) produksi tanaman tomat hanya berkisar 3,251 ton/ha pada tahun 2018, sedangkan produksi optimal tanaman tomat adalah 60 ton/ha. Rendahnya produksi tanaman tomat di Kabupaten Sintang diduga karena kondisi tanah PMK yang miskin bahan organik dan unsur haranya rendah, $\mathrm{pH}$ rendah, dan $\mathrm{Al}$ yang tinggi. Kabupaten Sintang memiliki jenis tanah PMK yaitu seluas 1,34 juta/ha atau sekitar 41,56\% dari luas wilayah sintang.

Usaha untuk memperbaiki kekurangan tanah PMK adalah dengan pemberian pupuk organik. Sudiarto dan Gusmaini (2004:40) menyatakan bahwa pupuk organik berperan penting dalam memperkaya bahan organik tanah yang diperlukan untuk penghidupan mikroba tanah dan pembentukan humus, memperbaiki struktur tanah sehingga tidak mudah rusak karena erosi percikan. Upaya peningkatan bahan organik tanah diantaranya dengan memberikan bokashi sekam padi. 


\section{METODOLOGI PENELITIAN}

Percobaan ini menggunakan metode eksperimen lapangan dan menggunakan rancangan lingkungan dengan pola rancangan acak kelompok (RAK), faktor perlakuaan dalam percobaan ini adalah bokashi sekam padi yang terdiri dari lima taraf, yaitu: $\mathrm{N}_{\mathrm{o}}=$ Tanpa bokashi sekam padi (kontrol); $\mathrm{N}_{1}=$ Bokashi sekam padi sebanyak 1,5 $\mathrm{kg} / \mathrm{m}^{2} ; \mathrm{N}_{2}=$ Bokashi sekam padi sebanyak $2 \mathrm{~kg} /$ $\mathrm{m} 2 ; \mathrm{N}_{3}=$ Bokashi sekam padi sebanyak $2,5 \mathrm{~kg} / \mathrm{m}^{2}$; $\mathrm{N}_{4}=$ Bokashi sekam padi sebanyak $3 \mathrm{~kg} / \mathrm{m}^{2}$. Satuan percobaan dalam penelitian ini adalah seluruh tanaman tomat pada masing-masing petak percobaan yaitu sebanyak 5 taraf perlakuan $\mathrm{x} 5$ ulangan $\mathrm{x} 4$ tanaman $=100$ tanaman. Tanaman yang diamati adalah seluruh tanaman.

Bahan yang diperlukan dalam penelitian ini terdiri dari benih tomat, sekam padi, gula merah, pupuk kandang kotoran ayam, $\mathrm{EM}_{4}$, papan, pestisida decis, furadan, tali rafia , bambu. Alat yang digunakan dalam penelitian ini adalah cangkul, parang, ember dan gembor, handspayer, meteran, termometer, seperangkat alat tulis, timbangan digital, kamera. Penelitian ini dilaksanakan Di Desa begori, Kecamatan serawai, Kabupaten Sintang.

\section{HASIL DAN PEMBAHASAN}

\section{Hasil Penelitian}

Hasil Pengamatan dalam penelitian ini untuk peubah tinggi tanaman, jumlah daun dan berat tanaman disajikan pada Tabel I berikut.

Tabel 1. Rerata tiap peubah

\begin{tabular}{|c|c|c|c|}
\hline \multirow{2}{*}{ Perlakuan } & \multicolumn{3}{|l|}{ Rerata } \\
\hline & Tinggi tanaman & Jumlah buah & Berat buah \\
\hline $\mathbf{N}_{0}$ & 31,65 & 5,20 & 155,35 \\
\hline $\mathbf{N}_{1}$ & 46,05 & 5,45 & 175,50 \\
\hline $\mathbf{N}_{2}$ & 55,85 & 6,40 & 202,65 \\
\hline $\mathbf{N}_{3}$ & 88,20 & 6,85 & 236,20 \\
\hline $\mathbf{N}_{4}^{3}$ & 89,80 & 7,85 & 307,05 \\
\hline Jumlah & 311,55 & 31,75 & 1076,75 \\
\hline
\end{tabular}

Sumber: Data hasil pengamatan

Keterangan: $\quad \mathrm{N}_{0}=$ Bokashi sekam padi (kontrol)

$\mathrm{N}_{1}=$ Bokashi sekam padi $=1,5 \mathrm{~kg} / \mathrm{m}^{2}$

$\mathrm{N}_{2}=$ Bokashi sekam padi $=2 \mathrm{~kg} / \mathrm{m}^{2}$

$\mathrm{N}_{3}=$ Bokashi sekam padi $=2,5 \mathrm{~kg} / \mathrm{m}^{2}$

$\mathrm{N}_{4}=$ Bokashi sekam padi $=3 \mathrm{~kg} / \mathrm{m}^{2}$

Rerata hasil pengamatan tinggi tanaman seperti yang terlihat pada Tabel 1 menunjukkan bahwa tanaman tertinggi dihasilkan oleh tanaman yang diberi $3 \mathrm{~kg}$ bokashi sekam padi perlakuan $\mathrm{b}_{4}$ dengan tinggi rata-rata $89,80 \mathrm{~cm}$, sedangkan rerata tinggi tanaman terkecil terlihat pada tanaman yang tidak diberi bokashi batang pisang perlakuan $\mathrm{b}_{0}$, yaitu $31,65 \mathrm{~cm}$. Hasil Pengamatan terhadap jumlah buah menunjukkan bahwa jumlah buah tertinggi dihasilkan oleh tanaman yang diberi $3 \mathrm{~kg}$ bokashi sekam padi dengan buah rata-rata 7,85 buah, sedangkan rerata jumlah buah terkecil terlihat pada tanaman yang tidak diberi bokashi sekam padi, yaitu 5,20 buah. Hasil pengamatan yang terlihat pada Tabel 1 menunjukkan bahwa berat buah tertinggi dihasilkan oleh tanaman yang diberi $3 \mathrm{~kg}$ bokashi sekam padi dengan berat rata-rata 307,05 $\mathrm{kg}$, sedangkan rerata berat terkecil terlihat pada tanaman yang tidak diberi bokashi sekam padi yaitu $155,35 \mathrm{~kg}$. Rerata dari pengamatan tinggi tanaman, 
jumlah buah dan berat buah kemudian dilanjutkan dengan analisis sidik ragam seperti yang ditampilkan pada Tabel 2.

Tabel 2. Analisi Ragam Perlakuan Terhadap Tiap Peubah

\begin{tabular}{|c|c|c|c|c|c|}
\hline \multirow[b]{2}{*}{ SK } & \multicolumn{3}{|l|}{ F hitung } & \multicolumn{2}{|c|}{$\mathrm{F}$ tabel } \\
\hline & $\begin{array}{l}\text { Tinggi } \\
\text { tanaman }\end{array}$ & $\begin{array}{l}\text { Jumlah } \\
\text { buah }\end{array}$ & Berat buah & 0,05 & 0,01 \\
\hline Kelompok & $1,06^{\mathrm{ns}}$ & $3,14^{*}$ & $7,00 * *$ & 3.01 & 4.77 \\
\hline Perlakuan & $300,89 * *$ & $21,14 * *$ & $41,80 * *$ & 3.01 & 4.77 \\
\hline
\end{tabular}

Sumber : Hasil analisis data

Keterangan : $\mathrm{ns}=$ Tidak berpengaruh pada selang kepercayaan 95\%

$* *=$ Berpengaruh pada selang kpercayaan $99 \%$

Hasil analisi sidik ragam pada Tabel 2 menunjukkan bahwa perlakuan sekam padi berpengaruh sangat nyata terhadap tinggi tanaman, jumlah buah dan berat buah tanaman tomat. Uji
Beda Nyata Jujur (BNJ) dilakukan untuk mengetahui taraf perlakuan pemberian bokashi sekam padi yang terbaik terhadap tinggi tanaman, jumlah buah dan berat buah tanaman tomat. Hasil Uji BNJ ditunjukkan pada Tabel 3.

Tabel 3. Uji Beda Nyata Jujur (BNJ) Terhadap Tiap Peubah

\begin{tabular}{|c|c|c|c|}
\hline \multirow[t]{2}{*}{ Perlakuan } & Tinggi Tanaman & Jumlah buah & Berat buah \\
\hline & \multicolumn{3}{|l|}{ Rerata } \\
\hline $\mathbf{N}_{0}$ & $31,65 \mathrm{a}$ & $5,20 \mathrm{a}$ & $155,35 \mathrm{a}$ \\
\hline $\mathbf{N}_{1}^{0}$ & $46,05 \mathrm{~b}$ & $5,45 \mathrm{a}$ & $175,50 \mathrm{ab}$ \\
\hline $\mathbf{N}_{2}^{1}$ & $55,85 \mathrm{c}$ & $6,40 \mathrm{~b}$ & $202,65 \mathrm{~b}$ \\
\hline $\mathbf{N}_{3}^{2}$ & $88,20 \mathrm{~d}$ & $6,85 \mathrm{~b}$ & $236,20 \mathrm{~b}$ \\
\hline $\mathbf{N}^{3}$ & $89,80 \mathrm{~d}$ & $7,85 \mathrm{c}$ & $307,05 \mathrm{c}$ \\
\hline BNJ 0,05 & 5.77 & 0.80 & 35.67 \\
\hline BNJ 0,01 & 7.32 & 1,20 & 45.22 \\
\hline
\end{tabular}

Sumber : Hasil analisi data

Keterangan : Angka yang diikuti huruf yang sama pada baris atau kolom yang sama menunjukkan berbeda tidak nyata

Hasil Uji BNJ seperti yang terlihat dalam Tabel 3 menunjukkan bahwa pemberian bokashi sekam padi pada dosis 2,50 kg per $\mathrm{m}^{2}\left(\mathrm{~N}_{3}\right)$ menghasilkan rerata tinggi tanaman yang tidak berbeda pada selang kepercayaan $95 \%$ dengan dosis 3,00 kg per $\mathrm{m}^{2}\left(\mathrm{~N}_{4}\right)$, lebih tinggi dibanding dosis $2,00 \mathrm{~kg}$ per $\mathrm{m}^{2}\left(\mathrm{~N}_{2}\right), 1,50 \mathrm{~kg}$ per $\mathrm{m}^{2}\left(\mathrm{~N}_{1}\right)$, dan tanpa pemberian bokashi sekam padi $\left(b_{o}\right)$. Berdasarkan hasil uji BNJ tersebut dinyatakan bahwa perlakuan yang memberikan rerata tinggi tanaman tertinggi adalah perlakuan $\mathrm{N}_{3}$. Pada perlakuan tersebut menghasilkan rerata tinggi tanaman $88,20 \mathrm{~cm}$. Untuk peubah jumlah daun menunjukkan bahwa pemberian bokashi sekam padi pada dosis $2,00 \mathrm{~kg}$ per $\mathrm{m}^{2}\left(\mathrm{~N}_{2}\right)$ menghasilkan rerata jumlah buah yang tidak berbeda pada selang kepercayaan $95 \%$ dengan dosis $2,50 \mathrm{~kg}$ per $\mathrm{m}^{2}$ $\left(\mathrm{N}_{3}\right)$, lebih banyak dibanding dosis $1,50 \mathrm{~kg}$ per $\mathrm{m}^{2}$
$\left(\mathrm{N}_{1}\right)$, dan tanpa pemberian bokashi batang pisang $\left(b_{o}\right)$.

Berdasarkan hasil uji BNJ tersebut dinyatakan bahwa perlakuan yang memberikan rerata jumlah buah terbanyak adalah perlakuan $\mathrm{N}_{4}$ menghasilkan rerata jumlah buah 7,85 buah. Hasil Uji BNJ untuk peubah berat buah menunjukkan bahwa bahwa pemberian bokashi sekam padi pada dosis $2,00 \mathrm{~kg}$ per $\mathrm{m}^{2}\left(\mathrm{~N}_{2}\right)$ menghasilkan rerata berat tanaman per rumpun yang tidak berbeda pada selang kepercayaan 95 $\%$ dengan dosis $2,50 \mathrm{~kg}$ per $\mathrm{m}^{2}\left(\mathrm{~N}_{3}\right)$, lebih berat dibanding dosis $1,50 \mathrm{~kg}$ per $\mathrm{m}^{2}\left(\mathrm{~N}_{1}\right)$, dan tanpa pemberian bokashi sekam padi $\left(b_{o}\right)$. Berdasarkan hasil uji BNJ tersebut dinyatakan bahwa perlakuan yang memberikan berat buah terberat adalah perlakuan $\mathrm{N}_{4}$. Pada perlakuan tersebut menghasilkan rerata berat buah $307,05 \mathrm{~g}$. 


\section{Peranan Pemberian Bokashi Sekam Padi Terhadap Pertumbuhan Dan Hasil Tanaman Tomat (Lycopersicum esculentum.Mill.)}

\section{Pembahasan}

Hasil penelitian ini menunjukan bahwa pemberian bokashi sekam padi berpengaruh sangat nyata terhadap pertumbuhan dan hasil tanaman tomat pada tanah PMK yang terlihat dari hasil pengamatan terhadap tinggi tanaman, jumlah buah, dan berat buah tanaman tomat. Hasil uji BNJ menunjukan bahwa pemberian bokashi sekam padi $2,5 \mathrm{~kg} / \mathrm{m}^{2}$ memberikan hasil terbaik terhadap pertumbuhan tanaman tomat dibandingkan taraf perlakuan lainya. Sedangkan pemberian bokashi sekam padi $3 \mathrm{~kg} / \mathrm{m}^{2}$ merupakan dosis terbaik menghasilkan jumlah buah dan berat buah tertinggi. Gadner, dkk., (1991) menyatakan bahwa pemberian unsur hara dalam jumlah yang banyak hanya menyebabkan peningkatan kandungan unsur hara didalam jaringan tanaman, namun tidak disertai dengan peningkatan pertumbuhan.

Hasil Uji BNJ diketahui bahwa pemberian bokashi sekam padi $3 \mathrm{~kg}$ tidak menghasilkan tinggi tanaman yang lebih tinggi, dibandingkan dengan pemberian $2,5 \mathrm{~kg} / \mathrm{m}^{2}$, hal ini diduga pada pemberian bokashi sekam padi $2,5 / \mathrm{m}^{2} \mathrm{~kg}$ telah mencapai batas optimal kebutuhan tanaman sehingga dengan penambahan dosis yang lebih tinggi tidak mempengaruhi tinggi tanaman. Dwi, dkk (2006) menyatakan bahwa setiap dosis yang diberikan akan mempengaruhi besar kecilnya kandungan hara dalam pupuk tersebut, tetapi belum dapat dijamin bahwa semakin besar dosis yang diberikan akan semakin meningkatkan hasil tanaman. Hal ini disebabkan karena tanaman memiliki batas dalam penyerapan unsur hara untuk kebutuhan hidupnya. Djiwosaputro (1990) menyatakan bahwa tanaman akan tumbuh dengan baik apabila unsur hara yang diberikan berada dalam jumlah yang seimbang dan sesuai dengan kebutuhan tanaman. Palimbungan, dkk (2006) menyatakan bahwa tersedianya unsur hara dalam jumlah yang cukup dan seimbang untuk pertumbuhan tanaman, dapat menyebabkan prosespembelahan, pembesaran sel akan berlangsung dengan cepat yang mengakibatkan beberapa organ tumbuh dengan cepat.

Hasil penelitian ini menunjukan bahwa bokashi sekam padi mampu memberikan pengaruh yang baik terhadap kondisi tanah. Hal ini diduga bokashi yang diberikan pada tanah PMK mampu PIPER No. 31 Volume 16 Oktober 2020 memperbaiki sifat fisik dan kimia tanah, kondisi tanah bisa menjadi lebih gembur sehingga perkembangan akar tanaman menjadi optimal dan unsur-unsur hara dapat diserap oleh tanaman. Gusmailina dan Komarayati (2003:21-30) menyatakan bahwa pupuk organik seperti bokashi sekam padi dapat memperbaiki struktur dan tekstur tanah. Penggunaan bokashi sekam padi mengurangi pemadatan tanah karena semakin banyak pori-pori, dan menyebabkan akar tanaman semakin tumbuh lebih baik, sehingga tingkat pengambilan hara semakin tinggi sesuai kebutuhan tanaman. Perkembangan system perakaran yang baik sangat menentukan pertumbuhan vegetataif tanaman yang pada akhirnya menentukan pula fase reproduktif dan hasil tanaman. Pertumbuhan vegetataif yang baik akan menunjang fase generatif.

Hasil uji BNJ menunjukan bahwa pemberian $3 \mathrm{~kg}$ bokashi sekam padi menghasilkan jumlah buah, dan berat buah tertinggi, hal ini diduga karena sifat dari bokashi sekam padi merupakan salah satu jenis pupuk organik dengan kandungan unsur hara yang tinggi, sehingga pada pemberian dosis yang tinggi pengaruh terhadap hasil tanaman demikian sebaliknya jika pemberian pada jumlah yang rendah hasil tanaman rendah. Setyamidjaja (1986:16) mengatakan bahwa unsur nitrogen yang ada dalam pupuk organik mampu mempengaruhi pertumbuhan meristem apikal untuk dapat berkembang. Zubachtirodin dan Subandi (2007:28) juga mengatakan bahwa tinggi tanaman dipengaruhi oleh pemberian nitrogen yang dapat meningkatkan tinggi tanaman. Peningkatan jumlah daun sangat dipengaruhi oleh unsur nitrogen, fosfor, dan kalium selain faktor lingkungan seperti suhu dan cahaya. Hal ini tidak terlepas dari fungsi ketiga unsur tersebut, bagi tanaman, yaitu dapat memacu pertumbuhan. Unsur nitrogen dapat memperbaiki pembelahan sel, pembentukan bunga. Rainsema (1983:66) menyatakan bahwa Fosfor sangat berperan aktif dalam menstransfer energi di dalam sel, berfungsi mengubah karbohidrat dan meningkatkan efisiensi kerja kloroplas. Peranan fosfor adalah memacu pertumbuhan dan pembentukan sistem perakaran yang dari benih dan 
tanaman muda, mempercepat pembungaan dan pemasakan buah,biji dan gabah, memperbesar persentase pembentukan bunga menjadi buah atau biji, sebagai bahan penyusun inti sel, lemak dan protein. unsur kalium dapat mengaktifkan enzim dan melancarkan proses penyerapan unsur hara (Harjadi, 1991:23).

Meningkatnya berat buah tanaman sangat dipengaruhi oleh jumlah sel-sel pembentuk jaringan tanaman. Sel-sel pembentuk jaringan tanaman ini sangat tergantung pada unsur hara yang ada dalam tanah. Pemberian bokashi sekam padi menyebabkan bahan organik tanah menjadi lebih baik. Syukur dan Indah (2006:124-131) menyatakan bahwa penambahan bahan organik ke dalam tanah, menyebabakan peningkatan $\mathrm{C}$ organik tanah yang dilepaskan ke dalam tanah. Akibat dari pemberian bokashi sekam padi pada tanah PMK menyebabkan kodisi tanah menjadi lebih baik terutama ketersediaan hara seperti $\mathrm{N}, \mathrm{P}, \mathrm{K}$, dan unsur-unsur hara mikro dan makro bagi tanaman.

\section{KESIMPULAN}

Hasil analisis data dalam penelitian ini disimpulkan: (1). Pemberian bokashi sekam padi mempengaruhi pertumbuhan dan hasil tanaman tomat pada tanah PMK, yang ditandai dengan tinggi tanaman, jumlah buah, dan berat buah. (2). Hasil tertinggi tanaman tomat pada penelitian ini ratarata pada pemberian $3 \mathrm{~kg}$ bokashi sekam padi, yang memberikan jumlah buah 7,85 buah per tanaman, dan berat buah 307,05 gram per tanaman.

\section{SARAN}

Berdasarkan hasil penelitian ini disarankan untuk: (1). Bokashi sekam padi sebanyak $3 \mathrm{~kg} / \mathrm{m}^{2}$ dapat diberikan untuk meningkatkan pertumbuhan dan hasil tanaman tomat pada tanah PMK. (2). Perlu dilakukan penelitian lanjutan menggunakan bokashi sekam padi dengan pemberian dosis yang lebih tinggi diatas $3 \mathrm{~kg} / \mathrm{m}^{2}$ agar diketahui hasil tanaman tomat yang lebih optimal.

\section{DAFTAR PUSTAKA}

BPS Kabupaten Sintang. 2018. Kabupaten Sintang dalam Angka. CV Bakti: BPS kabupaten sintang.

Cahyono Bambang, Ir. 1998. Tomat-Uasaha Tani dan Penanganan Pasca Panen. Kanisius. Yogyakarta

Dwi, C.O, Rejeki,A dan Teguh, S. 2006. Pengaruh Dosis Pupuk Organik Cair Dan Macam Tanah Terhadap Pertumbuhan Awal Mahkota Dewa (Phalleria macrocorpa). Universitas Tunas Pembangunan. Surakarta.

Djiwosaputra, D. 1990. Pengantar Fisiologi Tumbuhan. Jakarta: Gramedia

Gusmailina, G. P. Dan S. Komarayati. 2003. Pengembangan Penggunaan Arang Untuk Rehabilitasi Lahan. Bulletin Penelitian dan Pengembangan Kehutanan, Vol. 4 (1), halaman: 2130.

Harjadi. 1991. Pengantar Agronomi. Jakarta: PT Gramedia Pustaka Utama.

Palimbungan N, R. , dan F. Hamzah F. 2006 Pengaruh Ekstrak Daun Lamtoro Sebagai Pupuk Organik Cair Terhadap Pertumbuhan Dan Produksi Tanaman Sawi. J. Agrisistem Vol 2 (2) : 96-101.

Pracaya. 2003. Bertanam Tomat. Kanisius. Yogyakarta.

Rainsema, W.T. 1983. Pupuk Dan Pemupukan. Terjemahan H.M. Saleh. Bhratara Karya Aksara. Jakarta. Vii +232 h.

Sudiarto, dan Gusmaini. 2004. Pemanfaatan Bahan Organik In Situ Untuk Efisiensi Budidaya Jahe Yang Berkelanjutan.Jurnal Litbang Pertaniaan, 23 (2). 2004.

Syukur,A. dan N. M. Indah. 2006. Kajian Pengaruh Pemberian Macam Pupuk Organik Terhadap Peertumbuhan Dan Hasil Tanaman Jahe Di Inceptisol, Karanganyar. Jurnal Ilmu Tanah dan Lingkungan Vol. 6 (2), halaman: 124-131. 